\title{
Technological Development of Brewing in Domestic Refrigerator Using Freeze-Dried Raw Materials
}

\author{
Angelika-Ioanna Gialleli, Vassilios Ganatsios, Antonia Terpou, Maria Kanellaki*, \\ Argyro Bekatorou, Athanasios A. Koutinas and Dimitra Dimitrellou \\ Department of Chemistry, Food Biotechnology Group, University of Patras, GR-26500 Patras, Greece
}

Received: July 22, 2016

Accepted: May 10, 2017

\begin{abstract}
Summary
Development of a novel directly marketable beer brewed at low temperature in a domestic refrigerator combined with yeast immobilization technology is presented in this study. Separately, freeze-dried wort and immobilized cells of the cryotolerant yeast strain Saccharomyces cerevisiae AXAZ-1 on tubular cellulose were used in low-temperature fermentation $\left(2,5\right.$ and $\left.7{ }^{\circ} \mathrm{C}\right)$. The positive effect of tubular cellulose during low-temperature brewing was examined, revealing that freeze-dried immobilized yeast cells on tubular cellulose significantly reduced the fermentation rates in contrast to freeze-dried free cells, although they are recommended for home-made beer production. Immobilization also enhanced the yeast resistance at low-temperature fermentation, reducing the minimum brewing temperature value from 5 to $2{ }^{\circ} \mathrm{C}$. In the case of high-quality beer production, the effect of temperature and initial sugar concentration on the fermentation kinetics were assessed. Sensory enrichment of the produced beer was confirmed by the analysis of the final products, revealing a low diacetyl concentration, together with improved polyphenol content, aroma profile and clarity. The proposed process for beer production in a domestic refrigerator can easily be commercialized and applied by dissolving the content of two separate packages in tap water; one package containing dried wort and the other dried immobilized cells on tubular cellulose suspended in tap water.
\end{abstract}

Key words: brewing, low-temperature fermentation, novel technology, immobilized cells, freeze-drying, tubular cellulose

\section{Introduction}

A combination of immobilized biocatalysts and low-temperature fermentation has led to products with acceptable sensory characteristics $(1,2)$. For fermentations at extremely low temperatures (below $5{ }^{\circ} \mathrm{C}$ ), the use of psychrotolerant yeast strains is necessary. Such microorganisms exhibit cold shock response phenotypes with the accumulation of cryoprotectants (e.g. trehalose, glycerol and heat shock proteins), modification of transcription activity, and membrane fluidity changes $(3,4)$. Cold-adapted yeasts, such as the $S$. cerevisiae AXAZ-1 strain used in the present study, retain their viability and fermentation ability at low temperatures and have high potential for biotechnological applications. Immobilization of psychrophilic yeast strains has enabled the use of an extremely low brewing temperature $\left(0-7^{\circ} \mathrm{C}\right)$, leading to acceptable fermentation efficiency and product quality. Specifically, the combination of cell immobilization and low fermentation temperature has yielded products with low diacetyl concentration and improved ratios of the desired esters and unwanted volatile compounds (fusel alcohols) compared 
to free cell systems (4). Cell immobilization on tubular cellulose (5) resulted in high efficiency in fermentations at extremely low temperature, together with the high fermentation activity of freeze-dried cells (6). This opened a way for wine and beer making in a domestic refrigerator (7).

In previous studies, freeze-dried free and immobilized cells were used in low-temperature brewing with satisfactory fermentation kinetics and improved final beer quality (8). The aim of the present study is to develop a dry ready-to-use mixture of immobilized yeast biocatalyst on tubular cellulose and wort, and evaluate its suitability for brewing in a domestic refrigerator.

\section{Materials and Methods}

\section{Microorganism and media}

The alcohol-resistant, psychrotolerant lager yeast strain Saccharomyces cerevisiae AXAZ-1 (9) was grown in a synthetic medium containing (in g/L): $\mathrm{NH}_{4} \mathrm{SO}_{4} 1, \mathrm{KH}_{2} \mathrm{PO}_{4} 1$, $\mathrm{MgSO}_{4} 5$, glucose 40 and yeast extract 4 at $30{ }^{\circ} \mathrm{C}$ with aeration $\left(500 \mathrm{~cm}^{3} / \mathrm{min}, 700 \mathrm{~Pa}\right)$. The culture was harvested by centrifugation at $2000 \times g$ for $10 \mathrm{~min}$. Synthetic media with the above composition of nutrients but containing $120 \mathrm{~g} / \mathrm{L}$ of glucose were used for cell immobilization. Fermentation experiments were performed using hopped lager wort supplied by the Athenian Brewery S.A. (Patras, Greece). The $\mathrm{pH}$ value of wort was 5.0 and its relative density was $4.72^{\circ}$ Plato (specific gravity of 1.018). All media were autoclaved at $120^{\circ} \mathrm{C}$ and $101325 \mathrm{~Pa}$ for $15 \mathrm{~min}$ prior to use.

\section{Preparation of the support and cell immobilization}

The carrier used for cell immobilization in this study was a porous cellulosic material, tubular cellulose, produced after pine sawdust delignification with $1 \% \mathrm{NaOH}$, as described by Koutinas et al. (7). Pine tree sawdust was obtained from a local lumber mill in Patras. After delignification, tubular cellulose was sterilized by autoclaving at $120^{\circ} \mathrm{C}$ for $15 \mathrm{~min}$ and then dried at $37^{\circ} \mathrm{C}$ for $48 \mathrm{~h}$. Cell immobilization was carried out by suspending $7 \mathrm{~g}$ of the harvested wet yeast culture and $20 \mathrm{~g}$ of dry tubular cellulose in $500 \mathrm{~mL}$ of $120 \mathrm{~g} / \mathrm{L}$ of glucose medium. The system was allowed to ferment for $24 \mathrm{~h}$ at $30^{\circ} \mathrm{C}$ to a final density of $0.3{ }^{\circ}$ Plato (specific gravity of 1.001). The liquid was then decanted and the immobilized biocatalyst washed with $200 \mathrm{~mL}$ of fresh glucose $(120 \mathrm{~g} / \mathrm{L})$ medium.

\section{Freeze-drying of raw materials}

Amounts of the immobilized biocatalyst (65 g wet mass), yeast biomass ( $2 \mathrm{~g}$ wet mass) and wort were frozen separately to $-45^{\circ} \mathrm{C}$ at a cooling rate of $3{ }^{\circ} \mathrm{C} / \mathrm{min}$ using methanol as the freezing liquid in a Bio-Cool freezer (FTS Systems, New York, NY, USA). No cryoprotecting media were added (6). The frozen materials were freeze-dried overnight at $500 \mathrm{~Pa}$ and $-45^{\circ} \mathrm{C}$ in a Freeze Dry System (Daihan Labtech Co., Ltd, Namyangju, South Korea).

\section{Beer production using freeze-dried raw materials}

The freeze-dried immobilized biocatalyst (18 g dry mass) was introduced into a 1-litre glass cylindrical fer- menter. Sterilized deionized water was added to an appropriate amount of freeze-dried wort until the desirable sugar relative density (3.9, 4.7 and $6.9{ }^{\circ}$ Plato; i.e. specific gravity of 1.015, 1.018 and 1.027) was achieved (final volume of $500 \mathrm{~mL}$ ). Rehydrated wort and the biocatalyst were then mixed for fermentation and the effect of sugar concentration on fermentation kinetics was studied. Wort with optimum sugar concentration was used for fermentations in order to study the effects of temperature $(2,5$ and $7{ }^{\circ} \mathrm{C}$ ) on fermentation parameters. For comparison, freeze-dried free cells and wort were used for beer production under the same conditions as described above.

\section{Assays}

Fermentation kinetics was monitored by measuring relative density using the Plato hydrometer ( ${ }^{\circ}$ Plato) at various time intervals. Residual sugars were detected by high-performance liquid chromatography (HPLC) on a Shimadzu LC-9A HPLC (Shimadzu Co., Kyoto, Japan) system consisting of a Nucleogel ION 300 OA column, an LC-9A pump, an RID-6A refractive index detector, a CTO-10A column oven, and a DGU-2A degassing unit. The mobile phase was $0.004 \mathrm{M} \mathrm{H}_{2} \mathrm{SO}_{4}(0.5 \mathrm{~mL} / \mathrm{min}$; Merck Co., Darmstadt, Germany) and 1-propanol (1 \% by volume; Merck Co.) was used as an internal standard. The column temperature was $30{ }^{\circ} \mathrm{C}$, the sample dilution was $1 \%$ (by volume), and the injection volume was $40 \mu \mathrm{L}$.

Ethanol and methanol were determined by gas chromatography (GC) on a Shimadzu GC-8A system (Shimadzu Co.), with a HayeSep Q column, a C-R6A Chromatopack integrator, with $\mathrm{He}$ as carrier gas $(20 \mathrm{~mL} / \mathrm{min})$ and a flame ionization detector (FID). The column temperature was programmed at $80-180{ }^{\circ} \mathrm{C}\left(16^{\circ} \mathrm{C} / \mathrm{min}\right)$. The temperature of both the injector and detector was $200{ }^{\circ} \mathrm{C}$. A volume of $2 \mu \mathrm{L}$ of each sample was injected directly into the column and the concentration of ethanol/methanol was determined using standard curves. Ethanol productivity was calculated in grammes of ethanol per litre of liquid volume produced per day. Beer productivity was calculated in grammes of beer per litre of total working volume produced per day.

The polyphenol concentration, colour and bitterness of the beer samples were determined by the official methods of the European Brewery Convention (10).

Diacetyl was determined on an Agilent GC-7890-A GC system (Agilent Technologies Co., Los Angeles, CA, USA) with an Agilent HP-5 column, an Agilent 7697-A headspace sampler, and FID and electron capture detector (ECD) at 280 and $155^{\circ} \mathrm{C}$, respectively. Helium was used as carrier gas $(3 \mathrm{~mL} / \mathrm{min})$. The column temperature was programmed to rise from 40 to $250{ }^{\circ} \mathrm{C}$ (equilibration time $0.5 \mathrm{~min}$ ). Samples of $1 \mathrm{~mL}$ were injected into the column via the headspace sampler. Standard curves were constructed for quantitative analysis.

\section{Headspace SPME GC/MS analysis}

The identification and semi-quantitative analysis of the headspace volatiles was conducted using gas chromatography/mass spectrometry (GC/MS) and the solid phase microextraction method (SPME). Internal standard for semi-quantitative analysis was 2-pentanol $(1.62 \mathrm{mg} / \mathrm{L})$. 
The conditions of headspace-SPME sampling and GC-MS analysis were performed according to Gialleli et al. (11).

\section{Statistics}

All analyses were carried out in triplicate and the results are presented as mean value \pm standard deviation. The significance of differences in the mean values among various groups was checked by one-way analysis of variance (ANOVA) at the $5 \%$ level of significance.

\section{Results and Discussion}

\section{Rationale}

This research focuses on the development of an innovative, simple method that enables consumers to produce beer in their domestic refrigerators. The proposed technology is based on the use of freeze-dried tubular cellulose-supported biocatalyst in a dry mixture with freeze-dried wort, which can be dissolved in tap water and placed in a refrigerator for fermentation. The process is based on the feasibility of fermentation at extremely low temperature, positively affected by tubular cellulose, as reported in a previous study (7). Consequently, fermentation with wet tubular cellulose-supported biocatalyst and liquid wort has been studied due to the positive effect of tubular cellulose on volatiles during wort fermentation and beer characteristics $(7,12)$. Therefore, the experiments were designed to examine the freeze-dried wort and the biocatalytic effect on fermentation kinetics at low temperatures on the quality of the beer.

\section{Tubular cellulose - the key biocatalyst material}

Pine tubular cellulose, a nano/microporous cellulosic material obtained after delignification of sawdust, is a suitable material for use in food bioprocessing as a cell immobilization carrier. It is an abundant, low-cost, food-grade material that can be easily prepared and handled (13). The immobilized cells are attached to tubular cellulose due to physical adsorption by electrostatic and Van der Waals forces as well as by entrapment into the carrier tubes. It has been reported that the tubular cellulose presence increases sugar uptake rate by the immobilized cells due to the attraction by hydrogen bonding onto the tubular cellulose surface and continuous pumping of the sugar towards the cells (7). Calculation of the activation energy of maltose fermentation at low temperatures $(5,10$ and $15{ }^{\circ} \mathrm{C}$ ) showed that it was reduced by an average $42 \%$ when cells immobilized on tubular cellulose were used (14). This reduction of the activation energy was also observed during glucose alcoholic fermentations and supports the promotional activity of tubular cellulose and the extremely low temperature in wine making (7) and brewing (12).

\section{Low-temperature fermentation with dry raw materials - fermentation kinetics}

Fig. 1 shows the kinetics of freeze-dried wort fermentation by freeze-dried immobilized and free cells. In all cases, the freeze-dried immobilized cells promoted the fermentation of freeze-dried wort and required shorter adaptation periods than freeze-dried free cells, showing that these biocatalysts are ready to ferment after their drying. The protective activity of tubular cellulose on free yeast cells during freeze-drying and fermentation has also been illustrated in other studies $(6,12)$. The fermentation rates of free cells at $7{ }^{\circ} \mathrm{C}$ were lower than those of freeze-dried immobilized cells with all wort densities (3.9, 4.7, $6.9{ }^{\circ}$ Plato; i.e. specific gravity of $1.015,1.018$ and 1.027). Freeze-dried free cells did not exhibit the ability to ferment the wort at temperatures lower than $7{ }^{\circ} \mathrm{C}$ (data not shown). Furthermore, Fig. 2 indicates that the fermentation of freeze-dried wort by freeze-dried immobilized cells at 2 and $5{ }^{\circ} \mathrm{C}$ proceeds at similar fermentation rate and is completed after approx. 2 months. This result indicates the feasibility of fermenting freeze-dried wort with freeze-dried tubular cellulose-supported biocatalyst in a refrigerator.

In addition, the results in Table 1 show that ethanol and overall beer productivities during the fermentation using immobilized biocatalysts are higher than with free cells at $7^{\circ} \mathrm{C}$. The sugar relative density of $4.7^{\circ}$ Plato (specific gravity of 1.018) was used for further experiments at lower temperatures $\left(5\right.$ and $2{ }^{\circ} \mathrm{C}$ ) based on the higher fermentation rate than those of the other wort relative densities (3.9 and $6.9{ }^{\circ}$ Plato; i.e. specific gravity of 1.015 and 1.027) at $7^{\circ} \mathrm{C}$. Carbohydrates in wort comprise up to $92 \%$ of its total solids and include mainly the sugars maltose, maltotriose and glucose. Brewing strains utilize monosaccharides first and then the disaccharide maltose and finally the trisaccharide maltotriose (15). In the beer produced with freeze-dried immobilized cells and freeze-dried wort, the residual sugar was at low levels $(0.8-3.2 \mathrm{~g} / \mathrm{L})$. However, higher residual sugar values $(1.6-4.5 \mathrm{~g} / \mathrm{L})$ were obtained in fermentations with free cells at $7^{\circ} \mathrm{C}$ at all sugar densities. Beer obtained at $7{ }^{\circ} \mathrm{C}$ from freeze-dried wort in aqueous solution with the same starting relative density and produced by freeze-dried immobilized cells had alcohol volume fraction about $0.5 \%$ higher than those produced by freeze-dried free cells. This results in about a $10 \%$ higher beer yield and significantly affects beer productivity.

\section{Characteristics of beer produced in the refrigerator}

Table 2 compares the characteristics of the beer produced with freeze-dried biocatalysts, free cells and freeze-dried wort. Beer produced with the freeze-dried immobilized cells had colour values in the range of 9.3-16.7 on European Brewery Convention (EBC) scale, whereas the values for commercial lager beer range within 6-15 EBC. The colour intensity was lower than that of the beer fermented by freeze-dried free cells (12.6-20.4 EBC). The $\mathrm{pH}$ value of all types of beer produced by freeze-dried raw material and immobilized biocatalyst ranged between 4.0 and 4.3.

Polyphenols in beer, derived from malt and hops, play a significant role in foam maintenance, physical and chemical stability as well as antioxidant activity (16). In commercial beer, the polyphenol content is within the range of $190-250 \mathrm{mg} / \mathrm{L}$. Polyphenols in beer produced at 7 ${ }^{\circ} \mathrm{C}$ were reduced for about $20 \%$ when using immobilized compared to free cells. The polyphenols and colour values were higher when using a denser wort. Likewise, bitterness values were reduced when immobilized cells 

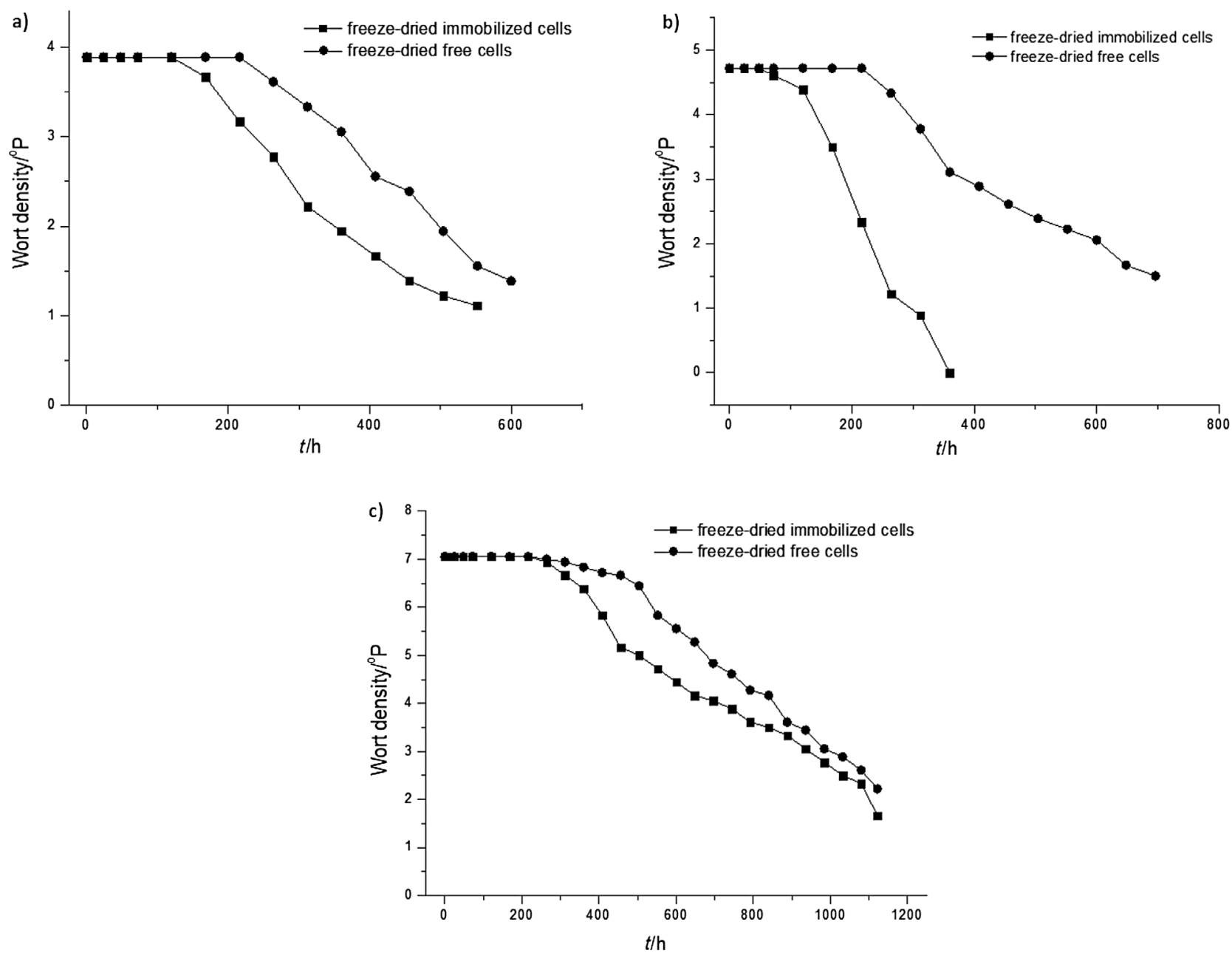

Fig. 1. Fermentation kinetics of freeze-dried wort at initial density of: a) $3.9^{\circ}$ Plato (specific gravity of 1.015 ), b) $4.7^{\circ} \mathrm{Plato}$ (specific gravity of 1.018), and c) $6.9^{\circ}$ Plato (specific gravity of 1.027) using freeze-dried free and immobilized yeast at $7^{\circ} \mathrm{C}$

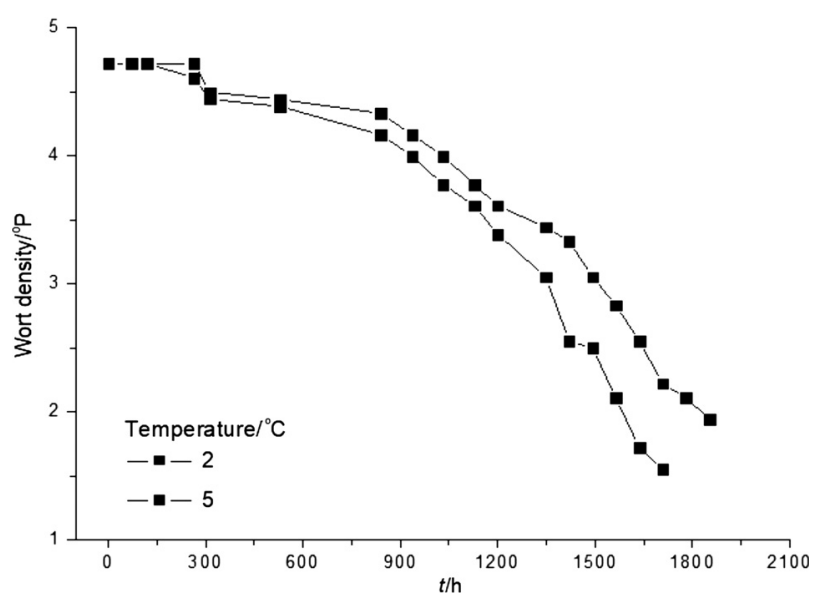

Fig. 2. Fermentation kinetics of freeze-dried wort $\left(4.7^{\circ}\right.$ Plato; i.e. specific gravity of 1.018) using freeze-dried immobilized yeast at 5 and $2{ }^{\circ} \mathrm{C}$

were used, due to adsorption of hop acids onto the tubular cellulose material, as reported in previous studies $(6,8)$. In commercial beer, bitterness can be adjusted with the addition of hop extracts and usually varies within the
10-40 European bitterness unit (EBU) range. In the case of fermentations at 2 and $5{ }^{\circ} \mathrm{C}$ using freeze-dried wort and immobilized cells, the bitterness and polyphenol values decreased along with the temperature reduction due to the longer contact of the fermenting wort with the tubular cellulose material. At all studied temperatures, the diacetyl concentration in beer was lower than its agreed taste threshold $(0.15 \mathrm{mg} / \mathrm{L})$, which is the optimum concentration for many types of beer (15). Diacetyl (2,3-butanedione), produced by yeast through the decarboxylation of $\alpha$-acetolactate, adds a buttery (or stale milk) aroma to beer and is undesirable to most consumers in concentrations above this taste threshold. In fermented products resulting from this research, beer diacetyl concentrations ranged from 0.06 to 0.15 and from 0.06 to $0.07 \mathrm{mg} / \mathrm{L}$ when using free and immobilized cells, respectively. The diacetyl content achieved in the beer is satisfactorily low and the maturation stage traditionally used for diacetyl concentration reduction can be avoided.

\section{Aroma profile}

The semi-quantitative analysis of volatile compounds was performed by SPME GC/MS to evaluate the effect of freeze-dried wort density on the aroma concentration of 
Table 1. Kinetic parameters of fermentations at various temperatures using freeze-dried wort with freeze-dried biocatalysts in aqueous solution

\begin{tabular}{|c|c|c|c|c|c|c|}
\hline Wort density & Temperature & $t$ & $\gamma$ (residual sugar) & $\varphi($ ethanol $)$ & Ethanol productivity & Beer productivity \\
\hline${ }^{\circ} \mathrm{P}$ & ${ }^{\circ} \mathrm{C}$ & $\mathrm{h}$ & $\mathrm{g} / \mathrm{L}$ & $\%$ & $\mathrm{~g} /(\mathrm{L} \cdot$ day $)$ & $\mathrm{g} /(\mathrm{L} \cdot$ day $)$ \\
\hline \multicolumn{7}{|c|}{ Freeze-dried free cells } \\
\hline 3.9 & 7 & 600 & 1.6 & 5.4 & 1.7 & 33.6 \\
\hline 4.7 & 7 & 696 & 2.1 & 5.8 & 1.6 & 29.0 \\
\hline 6.9 & 7 & 1122 & 4.5 & 7.7 & 1.3 & 18.0 \\
\hline \multicolumn{7}{|c|}{ Freeze-dried immobilized cells } \\
\hline 3.9 & 7 & 552 & 1.1 & 6.0 & 2.1 & 36.5 \\
\hline 4.7 & 7 & 360 & 0.8 & 6.2 & 3.3 & 56.0 \\
\hline 4.7 & 5 & 1708 & 1.5 & 5.7 & 0.6 & 11.8 \\
\hline 4.7 & 2 & 1852 & 2.2 & 5.4 & 0.6 & 10.9 \\
\hline 6.9 & 7 & 1120 & 3.2 & 8.2 & 1.4 & 18.0 \\
\hline
\end{tabular}

Table 2. Characteristics of beer produced at various temperatures by fermentation using mixtures of freeze-dried wort with freeze-dried biocatalysts

\begin{tabular}{|c|c|c|c|c|c|}
\hline$\frac{\text { Wort density }}{{ }^{\circ} \mathrm{P}}$ & $\frac{\text { Temperature }}{{ }^{\circ} \mathrm{C}}$ & $\frac{\gamma \text { (polyphenols) }}{\mathrm{mg} / \mathrm{L}}$ & $\frac{\text { Colour }}{\text { EBC }}$ & $\frac{\text { Bitterness }}{\text { EBU }}$ & $\frac{\gamma(\text { diacetyl })}{\mathrm{mg} / \mathrm{L}}$ \\
\hline \multicolumn{6}{|c|}{ Freeze-dried free cells } \\
\hline 3.9 & 7 & $213 \pm 10$ & $12.6 \pm 0.3$ & $28.6 \pm 1.1$ & $0.146 \pm 0.007$ \\
\hline 4.7 & 7 & $304 \pm 17$ & $15.9 \pm 0.6$ & $25.8 \pm 1.0$ & $0.110 \pm 0.005$ \\
\hline 6.9 & 7 & $358 \pm 13$ & $20.4 \pm 1.0$ & $27.8 \pm 1.2$ & $0.061 \pm 0.003$ \\
\hline \multicolumn{6}{|c|}{ Freeze-dried immobilized cells } \\
\hline 3.9 & 7 & $180 \pm 7$ & $9.3 \pm 0.4$ & $14.2 \pm 0.5$ & $0.065 \pm 0.003$ \\
\hline 4.7 & 7 & $256 \pm 14$ & $14.3 \pm 0.6$ & $16.5 \pm 0.7$ & $0.057 \pm 0.001$ \\
\hline 4.7 & 5 & $211 \pm 10$ & $9.8 \pm 0.5$ & $8.0 \pm 0.5$ & $0.062 \pm 0.001$ \\
\hline 4.7 & 2 & $179 \pm 8$ & $8.8 \pm 0.3$ & $6.7 \pm 0.3$ & $0.079 \pm 0.001$ \\
\hline 6.9 & 7 & $302 \pm 16$ & $16.7 \pm 0.7$ & $16.1 \pm 0.7$ & $0.058 \pm 0.001$ \\
\hline
\end{tabular}

$\mathrm{EBC}=$ European Brewery Convention, EBU=European bitterness unit

the beer produced by freeze-dried free and immobilized cells. In Table 3 (17-20), the majority of the identified compounds were esters that have low flavour thresholds and are considered to have a major impact on beer flavour. Various organic acids, carbonyl compounds, alcohols and terpenoids were also determined in all samples.

The semi-quantitative analysis, with 2-pentanol as internal standard, showed that in all cases the freeze-dried immobilized cells yielded products with higher total headspace volatile content. Specifically, the total amount of esters formed by freeze-dried immobilized cells was higher than that by free cells, at all wort sugar densities prepared using freeze-dried wort. The detected esters produced a flowery, fruity aroma in the products and are highly desirable (within certain limits) in beer. The concentrations of alcohols, carbonyl compounds, organic acids and terpenoids in the beer produced by freeze-dried free cells were not significantly different $(p>0.05)$ from those produced by freeze-dried immobilized cells. The alcohols in the products are mainly aliphatic, amyl or aromatic fusel alcohols that are not highly favourable for beer aroma. However, phenyl ethyl alcohol provides a sweet rose-like flavour that positively contributes to beer aroma and it was detected in higher concentration in the beer produced by freeze-dried immobilized cells. In addition, terpenes (Table 4), which are isoprene compounds derived from hops, add a flowery note to beer aroma (15) and their concentration was higher in the beer produced using freeze-dried immobilized cells on tubular cellulose.

Beer with the highest level of volatile compounds $(6013.2 \mu \mathrm{g} / \mathrm{L})$ compared to all other fermentation products was produced when fermenting freeze-dried wort of $4.7^{\circ}$ Plato (specific gravity of 1.018 ) by freeze-dried immobilized yeast cells. As shown in Table 4, the decrease in fermentation temperature leads to a reduction of the total concentration of volatile compounds (esters and alcohols), but the number of the total compounds detected was similar.

\section{Practical applications of the novel brewing method}

The proposed process is mainly based on the use of freeze-dried wort and brewer's phychrophilic yeast strain on freeze-dried tubular cellulose. Freeze-dried wort and a biocatalyst can be packaged separately or in the same 
Table 3. Volatile compounds identified in the beer produced by fermentation using mixtures of freeze-dried wort with freeze-dried biocatalysts at $7{ }^{\circ} \mathrm{C}$

\begin{tabular}{|c|c|c|c|c|c|c|c|}
\hline \multirow{4}{*}{ KI } & \multirow{4}{*}{ Compound } & \multicolumn{6}{|c|}{ Wort density $/{ }^{\circ} \mathrm{P}$} \\
\hline & & 3.9 & 4.7 & 6.9 & 3.9 & 4.7 & 6.9 \\
\hline & & \multicolumn{6}{|c|}{$\gamma($ volatile compound $) /(\mu \mathrm{g} / \mathrm{L})$} \\
\hline & & \multicolumn{3}{|c|}{ Freeze-dried free cells } & \multicolumn{3}{|c|}{ Freeze-dried immobilized cells } \\
\hline & Esters & & & & & & \\
\hline 847 & Ethyl acetate $^{a}$ & 33.5 & 45.6 & 12.9 & 27.0 & 55.1 & 16.1 \\
\hline 1011 & Ethyl butanoate $^{\mathrm{b}}$ & 3.1 & 5.0 & n.d. & 10.9 & 36.3 & 20.0 \\
\hline 1104 & 3-Methyl-butyl acetate ${ }^{\mathrm{b}}$ & 10.8 & 12.3 & 20.1 & 72.3 & 367.3 & 76.7 \\
\hline 1227 & Ethyl hexanoate $^{\mathrm{a}}$ & 20.0 & 22.7 & 34.0 & 115.2 & 141.2 & 100.3 \\
\hline 1259 & Hexyl acetate $^{e}$ & n.d. & 3.7 & 2.2 & n.d. & n.d. & n.d. \\
\hline 1298 & Ethyl heptanoate $^{c}$ & n.d. & n.d. & n.d. & 31.5 & 3.0 & 8.4 \\
\hline 1389 & Ethyl octanoate $^{a}$ & 47.8 & 52.4 & 81.2 & 837.1 & 1444.5 & 625.0 \\
\hline 1425 & Octyl acetate & n.d. & 6.1 & n.d. & n.d. & n.d. & n.d. \\
\hline 1588 & Ethyl decanoate $^{c}$ & n.d. & n.d. & 29.3 & 123.3 & 482.4 & 221.8 \\
\hline 1645 & Ethyl-9-decenoate & 41.7 & 29.8 & 120.4 & 1005.8 & 1066.7 & 650.2 \\
\hline \multirow[t]{4}{*}{1782} & 2-Phenyl ethyl acetate ${ }^{a}$ & n.d. & n.d. & n.d. & 46.3 & 71.9 & 28.0 \\
\hline & $N($ esters) & 6 & 8 & 7 & 9 & 9 & 9 \\
\hline & $\Sigma \gamma($ esters $)$ & 156.9 & 177.6 & 297.9 & 2269.4 & 3668.4 & 1746.5 \\
\hline & Organic acids & & & & & & \\
\hline 2047 & Octanoic acid ${ }^{\mathrm{a}}$ & 148.7 & 43.2 & 104.0 & 447.1 & 400.0 & n.d. \\
\hline 2252 & Decanoic acid ${ }^{\mathrm{b}}$ & 50.5 & 10.7 & n.d. & 290.7 & 512.1 & 426.5 \\
\hline 2266 & Undecanoic acid ${ }^{\mathrm{d}}$ & n.d. & n.d. & n.d. & n.d. & 71.8 & n.d. \\
\hline \multirow[t]{4}{*}{2318} & Undecylenic acid $^{\mathrm{b}}$ & n.d. & n.d. & n.d. & 306.5 & 244.1 & 277.0 \\
\hline & $N$ (organic acids) & 2 & 2 & 1 & 3 & 4 & 2 \\
\hline & $\Sigma \gamma($ organic acids $)$ & 199.2 & 53.9 & 104.0 & 1044.3 & 1228.0 & 703.5 \\
\hline & Alcohols & & & & & & \\
\hline 1213 & 2-Methyl-1-butanol ${ }^{\mathrm{d}}$ & 109.4 & 92.2 & 109.7 & 150.4 & 302.2 & 211.6 \\
\hline 1322 & 1-Hexanol ${ }^{\mathrm{b}}$ & n.d. & 2.5 & n.d. & n.d. & n.d. & n.d. \\
\hline 1504 & 1-Octanol ${ }^{e}$ & n.d. & 9.4 & n.d. & n.d. & 2.7 & n.d. \\
\hline 1611 & 2-Furanmethanol ${ }^{c}$ & n.d. & n.d. & n.d. & 34.2 & n.d. & n.d. \\
\hline \multirow[t]{4}{*}{1880} & Phenyl ethyl alcohol ${ }^{a}$ & 55.5 & 52.8 & 56.4 & 111.4 & 764.8 & 309.0 \\
\hline & $N($ alcohols $)$ & 2 & 4 & 2 & 3 & 3 & 2 \\
\hline & $\Sigma \gamma$ (alcohols) & 164.9 & 156.9 & 166.1 & 296.0 & 1069.7 & 520.6 \\
\hline & Carbonyl compounds & & & & & & \\
\hline 1353 & Nonanal $^{\mathrm{b}}$ & n.d. & n.d. & 4.1 & 6.7 & 20.8 & 13.0 \\
\hline \multirow[t]{4}{*}{1448} & Decanal $^{a}$ & 3.4 & 2.2 & n.d. & n.d. & 7.5 & n.d. \\
\hline & $N$ (carbonyl compounds) & 1 & 1 & 1 & 1 & 2 & 1 \\
\hline & $\Sigma \gamma$ (carbonyl compounds) & 3.4 & 2.2 & 4.1 & 6.7 & 28.3 & 13.0 \\
\hline & Terpenoids & & & & & & \\
\hline 1167 & Limonene $^{e}$ & n.d. & n.d. & 4.9 & n.d. & 18.8 & n.d. \\
\hline 1652 & $\alpha$-terpineol ${ }^{\mathrm{a}}$ & 5.4 & n.d. & n.d. & n.d. & n.d. & 2.8 \\
\hline 1721 & Citronellol $^{\mathrm{e}}$ & 3.1 & n.d. & n.d. & 12.0 & n.d. & n.d. \\
\hline \multirow[t]{3}{*}{2008} & Nerolidol $^{\mathrm{b}}$ & 8.1 & 7.7 & n.d. & 13.2 & n.d. & 3.6 \\
\hline & $N$ (terpenoids) & 3 & 1 & 1 & 2 & 1 & 2 \\
\hline & $\Sigma \gamma($ terpenoids $)$ & 16.6 & 7.7 & 4.9 & 25.2 & 18.8 & 6.4 \\
\hline \multicolumn{2}{|c|}{$N($ all compounds) } & 14 & 16 & 12 & 18 & 19 & 16 \\
\hline \multicolumn{2}{|c|}{$\Sigma \gamma($ all compounds $)$} & 541.0 & 398.3 & 577.0 & 3641.6 & 6013.2 & 2990.0 \\
\hline
\end{tabular}

KI=tentative identification by Kovats retention index; ${ }^{\mathrm{a}}(17),{ }^{\mathrm{b}}(18),{ }^{\mathrm{c}}(19),{ }^{\mathrm{d}}$ identification by mass spectra obtained from NIST107, NIST21 and SZTERP libraries, ${ }^{\mathrm{e}}(20)$; n.d. $=$ not detected 
Table 4 . Volatile compounds identified in the beer produced by fermentation using mixtures of freeze-dried wort $\left(4.7^{\circ} \mathrm{Plato}\right.$; i.e. specific gravity of 1.018) with freeze-dried biocatalysts

\begin{tabular}{lrrr}
\hline \multirow{2}{*}{ Compound } & \multicolumn{3}{c}{ Temperature $/{ }^{\circ} \mathrm{C}$} \\
\cline { 2 - 4 } & \multicolumn{1}{c}{7} & 5 & \multicolumn{1}{c}{2} \\
\cline { 2 - 4 }$N($ volatile compound $) /(\mu \mathrm{g} / \mathrm{L})$ \\
\hline Total concentration & 9668.4 & 3115.7 & 6 \\
$N($ organic acids $)$ & 4 & 5 & 4 \\
Total concentration & 1228.0 & 1150.8 & 985.7 \\
$N($ alcohols $)$ & 3 & 3 & 4 \\
Total concentration & 1069.7 & 985.4 & 910.9 \\
$N$ (carbonyl compounds) & 2 & 2 & 3 \\
Total concentration & 28.3 & 30.9 & 24.1 \\
$N$ (terpenes) & 1 & 1 & 1 \\
Total concentration & 18.8 & 14.4 & 13.5 \\
$N($ detected compounds) & 19 & 19 & 18 \\
Total volatile compound & 6013.2 & 5297.2 & 4709.4 \\
concentration & & & \\
\hline
\end{tabular}

container. These dry raw materials can be used as commercial product. A consumer will be able to conveniently suspend the dry raw materials in water in a bottle or small barrel. The fermentation vessel is then stored in a domestic refrigerator and beer produced with 3-5\% alcohol by volume after 10-15 days, depending on the refrigerator temperature $\left(2-7^{\circ} \mathrm{C}\right)$. Carbon dioxide is contained in the beer after sealing the vessel when the relative density of fermented broth is below 0.8 .

The home-scale application of the technology provides the opportunity for a consumer to produce good-quality, home-made beer easily and at low cost in the domestic refrigerator. In addition, the immobilization of cells on tubular cellulose, an abundant and cheap support, results in a clearer final product with improved aroma characteristics than beer produced with free yeast cells. This proposed technology is an interesting alternative to conventional home brewing methods and can provide potentially high-quality beer with possible commercialization potential.

\section{Conclusions}

The use of a freeze-dried biocatalyst of Saccharomyces cerevisiae cells immobilized on pine tubular cellulose has been proved effective for the low-temperature brewing of freeze-dried wort. Freeze-dried free cells cannot otherwise be used for brewing in a domestic refrigerator because they are not able to complete the fermentation at temperatures lower than $5{ }^{\circ} \mathrm{C}$. The beer produced by freeze-dried immobilized cells generally had good clarity, satisfactory volatile compound concentrations together with lower diacetyl and polyphenol contents than commercial beer. The proposed technology of beer production in a domestic refrigerator shows high commercialization potential as brewing kit using single-use packages of freeze-dried wort and a freeze-dried biocatalyst on tubular cellulose.

\section{Acknowledgements}

This project is implemented under the 'ARISTEIA' Action of the 'Operational Programme Education and Lifelong Learning' and is co-funded by the European Social Fund (ESF) and Greek National Resources. The authors would like to thank the Athenian Brewery S.A. for wort supply and technical support.

\section{References}

1. Willaert R, Nedovic VA. Primary beer fermentation by immobilized yeast - a review on flavor formation and control strategies. J Chem Technol Biotechnol. 2006;81:1353-67. https://doi.org/10.1002/jctb.1582

2. Bekatorou A, Plessas S, Mantzourani I. Biotechnological exploitation of brewery solid wastes for recovery or production of value-added products. In: Ravishankar RV, editor. Advances in food biotechnology. West Sussex, UK: John Wiley \& Sons; 2015. pp. 393-414. https://doi.org/10.1002/10.1002/9781118864463.ch24

3. Inouye $\mathrm{M}$, Phadtare $\mathrm{S}$. Cold shock response and adaptation to near-freezing temperature in cold-adapted yeasts. In: Buzzini P, Margesin R, editors. Cold-adapted yeasts: biodiversity, adaptation strategies and biotechnological significance. Heidelberg, Germany: Springer-Verlag GmbH; 2014. pp. 243-57.

https://doi.org/10.1007/978-3-642-39681-6_11

4. Kanellaki M, Bekatorou A, Koutinas AA. Low-temperature production of wine, beer and distillates using cold-adapted yeasts. In: Buzzini P, Margesin R, editors. Cold-adapted yeasts: biodiversity, adaptation strategies and biotechnological significance. Germany, Heidelberg: Springer Verlag-GmbH; 2014. pp. 417-39. https://doi.org/10.1007/978-3-642-39681-6_19

5. Bardi E, Koutinas AA. Immobilization of yeast on delignified cellulosic material for room temperature and low temperature wine making. J Agric Food Chem. 1994;42:221-6. https://doi.org/10.1021/jf00037a040

6. Bekatorou A, Koutinas AA, Psarianos K, Kanellaki M. Low-temperature brewing by freeze-dried immobilized cells on gluten pellets. J Agric Food Chem. 2001;49:373-7. https://doi.org/10.1021/jf000898b

7. Koutinas AA, Sypsas V, Kandylis P, Michelis A, Bekatorou A, Kourkoutas Y, et al. Nano-tubular cellulose for bioprocess technology development. PLoS One. 2012;7:334-50. https://doi.org/10.1371/journal.pone.0034350

8. Bekatorou A, Soupioni M, Koutinas AA, Kanellaki M. Low-temperature brewing by freeze-dried immobilized cells. Appl Biochem Biotechnol. 2002;97;105-21. https://doi.org/10.1385/ABAB:97:2:105

9. Argiriou T, Kaliafas A, Psarianos K, Kanellaki M, Voliotis S, Koutinas AA. Psychrotolerant Saccharomyces cerevisiae strains after an adaptation treatment for low temperature wine making. Process Biochem. 1996;31:639-43. https://doi.org/10.1016/S0032-9592(96)00016-7

10. European Brewery Convention: Analytica EBC, 1987. European Brewery Convention and Fachverlag Hans Carl GmbH: Nürnberg, Germany; pp. E155-7. Available from: www.analytica-ebc.com.

11. Gialleli AI, Bekatorou A, Kanellaki M, Nigam P, Koutinas AA. Apple juice preservation through microbial adsorption by nano/micro-tubular cellulose. Innov Food Sci Emerg Technol. 2016;33:416-21. https://doi.org/10.1016/j.ifset.2015.11.006

12. Bardi EP, Koutinas AA, Soupioni MJ, Kanellaki ME. Immobilization of yeast on delignified cellulosic material for low 
temperature brewing. J Agric Food Chem. 1996;44:463-7. https://doi.org/10.1021/jf9501406

13. Kourkoutas $\mathrm{Y}$, Bekatorou A, Banat IM, Marchant R, Koutinas AA. Immobilization technologies and support materials suitable in alcoholic beverages production: a review. Food Microbiol. 2004;21:377-97.

https://doi.org/10.1016/j.fm.2003.10.005

14. Ganatsios V, Koutinas AA, Bekatorou A, Kanellaki M, Nigam P. Promotion of maltose fermentation at extremely low temperatures using a cryotolerant Saccharomyces cerevisiae strain immobilized on porous cellulosic material. Enzyme Microb Technol. 2014;66:56-9. https://doi.org/10.1016/j.enzmictec.2014.08.007

15. Willaert R. Biochemistry of beer fermentation. In: Simpson BK, Nollet LML, Toldrá F, Benjakul S, Paliyath G, Hui YH, editors. Food biochemistry and food processing. Sussex, UK: John Wiley \& Sons; 2012. pp. 627-53. https://doi.org/10.1002/9781118308035.ch33

16. Piazzon A, Forte M, Nardini M. Characterization of phenolics content and antioxidant activity of different beer types. J Agric Food Chem. 2010;58:10677-83. https://doi.org/10.1021/jf101975q
17. Riu-Aumatell M, Miró P, Serra-Cayuela A, Buxaderas S, López-Tamames E. Assessment of the aroma profiles of low-alcohol beers using HS-SPME-GC-MS. Food Res Int. 2014;57: 196-202. https://doi.org/10.1016/j.foodres.2014.01.016

18. Kandylis P, Mantzari A, Koutinas AA, Kookos IK. Modelling of low temperature wine-making, using immobilized cells. Food Chem. 2012;133:1341-8. https://doi.org/10.1016/j.foodchem.2012.02.022

19. Kandylis P, Drouza C, Bekatorou A, Koutinas AA. Scale-up of extremely low temperature fermentations of grape must by wheat supported yeast cells. Bioresour Technol. 2010;101: 7484-91. https://doi.org/10.1016/j.biortech.2010.04.031

20. Prompona KD, Kandylis P, Tsakiris A, Kanellaki M, Kourkoutas Y. Application of alternative technologies for elimination of artificial colorings in alcoholic beverages produced by Citrus medica and potential impact on human health. Food Nutr Sci. 2012;3:959-69. https://doi.org/10.4236/fns.2012.37127 